\title{
A thematic analysis of higher education students' perceptions of online learning in Hong Kong under COVID-19: Challenges, strategies and support
}

\author{
Matthew W. L. Yeung ${ }^{1}$ (D) Alice H. Y. Yau ${ }^{2}$
}

Received: 30 January 2021 / Accepted: 27 June 2021 / Published online: 15 August 2021

(c) The Author(s), under exclusive licence to Springer Science+Business Media, LLC, part of Springer Nature 2021

\begin{abstract}
Under the sudden outbreak of COVID-19 worldwide, students were forced to switch from face-to-face to online learning. This study reports the experience of Hong Kong students in higher education concerning the challenges they faced, the strategies they used and the support they needed in their online learning during the period. An online questionnaire was used to invite students to answer open-ended questions about these three aspects. 145 students from two higher education institutions completed the questionnaire and their comments were coded using thematic analysis. The study has discovered that socio-economic factors may have presented difficulties to students' online learning concerning their study environment and access to equipment. Students were emotionally distressed by online learning, particularly by the quality of feedback and clarity of course arrangement, so support for these aspects should be given. Self-regulated learning strategies were found to have been deployed by students to facilitate their learning, in which the use of time management apps and lecture videos highlights the increasing importance of technology to self study. These socio-economic, technological and emotional factors will be further discussed and corresponding suggestions will be made to help teachers and university policy makers examine the conditions that can help improve and promote online learning for higher education students under COVID-19.
\end{abstract}

Keywords COVID-19 • Online teaching · Perception study · Thematic analysis · Self-regulated learning strategies

Matthew W. L. Yeung

yeungmatty@gmail.com

Alice H. Y. Yau

aliceyau.alice@gmail.com

1 The English Language Teaching Unit, The Chinese University of Hong Kong, Rm 436, 4/F, Li Dak Sum Building, The Chinese University of Hong Kong, Hong Kong, China

2 The Centre for Applied English Studies, The University of Hong Kong, Room 6.27, 6/F, Run Run Shaw Tower, Hong Kong, China 


\section{Introduction}

The higher education sector in Hong Kong has experienced an unprecedented shift from traditional face-to-face teaching to online teaching since late November 2019. First, a social political movement brought about on-going protests in the city that forced institutions to conduct online teaching for the last few weeks of the semester. After that, due to the widespread of Coronavirus disease (COVID19), classes were suspended again. To achieve the goal of "suspending classes without suspending learning" (Yeung, 2020, para. 1) while keeping everyone safe, all institutions made a complete switch to full online teaching in early 2020 for the whole semester, each exercising their own practices and strategies, for example, asynchronous courses or synchronous live online classes incorporating with some asynchronous activities. Although school offices and facilities remained open with some special arrangement on the opening hours, campuses were operated in a low-density environment, encouraging all the teaching staff and students to work and study at home. This pandemic has also led to the closure of schools in China, the United States, the United Kingdom and Australia, affecting millions of students globally (Crawford et al., 2020). A smooth transition from face-toface learning to online learning cannot be done overnight, and various challenges and obstacles faced by both teachers and students are expected. Previous studies on online learning have yet to capture the impacts of such abrupt transition on students, as they were mostly conducted when online courses were offered on a voluntary basis or in a much smaller scale (see Cacheiro-Gonzalez et al., 2019). Even though the growing literature of online learning under COVID-19 has provided some accounts of what students faced and needed in their online learning (see Aristovnik et al., 2020), it has yet to examine how students attempted to facilitate their own learning with their strategies. Therefore, taking the current education disruption as an object of study, this paper aims to provide a comprehensive picture of the challenges students faced, the support they needed and the strategies they used in their online learning during this sudden shift.

\section{Online learning}

In the last two decades, many universities have undergone transition and transformation in education from complementing face-to-face teaching with online components (e.g. blended or flipped learning) to fully implementing online courses with asynchronous and synchronous communicative tools (Kauffman, 2015; Wong et al., 2019). With a growing interest in lifelong learning, budget control and innovative teaching, institutions are highly motivated to develop online learning to meet the increasing demand for higher education and to be more competitive in face of globalisation and technological change (Lee-Post \& Hapke, 2017; Prior et al., 2016; Sun \& Chen, 2016). In 2018, around seven million students in the U.S. enrolled in online courses with $53 \%$ taking at least one course online and 
47\% in fully online programmes (National Center for Education Statistics, 2019). In China, more than 500 Massive Open Online Courses (MOOC) are offered with nearly 300 million people to enroll (Bao, 2020). Online learning has evolved into different stages from one-way learning (where participants independently view course instructional materials with minimal interaction with instructors) to collaborative learning (where students interact with their peers and instructors asynchronously or synchronously) (Smart \& Cappel, 2006). Constructivist-based pedagogies have been used in online learning with an emphasis on interaction, collaboration and reflection among students to connect and co-construct knowledge and learning experience in this virtual space as if they are experiencing the same in face-to-face learning (e.g. Arasaratnam-Smith \& Northcote, 2017; Mattar, 2018; Ruey, 2010). Yet, despite the growing experience with online learning, teachers and students still seemed to be under-prepared for it as shown by their experience during public health crises.

During the outbreak of SARS in Asia in 2003 (e.g. Denman, 2005; McNaught, 2004; Patil \& Chan, 2003; Wong et al., 2007) and H1N1 flu pandemic in the U.S in 2009 (e.g. Allen \& Seaman, 2010; Cauchemez et al., 2009), classes were similarly suspended and online learning was adopted. One major problem of online learning is related to the unpreparedness of teachers and students in which the former needed to adapt instructions and content originally designed for face-to-face delivery to online delivery within a very narrow window of time (Feast \& Bretag, 2005) while the latter had the added pressure to be expected to study independently (McNaught, 2004). What complicated teachers' online teaching was their lack of technical knowledge and skills in using technology (Lee \& Tsai, 2010). Even when teaching could be conducted online, both teachers and students expressed a sense of isolation as they were unable to see each other (Chan, 2003) and their communication could only be done by texts through emails or online discussions (McNaught, 2004). Therefore, maintaining communication and reducing isolation became the key considerations staff members had to take into when making the adaptations (McNaught, 2004; Wong, 2004). These studies have enabled institutions and teachers to reflect on and explore teaching with the use of communication technology (Bonk \& Kim, 2005) and have indeed provided an invaluable direction for schools to handle similar crises. However, these studies on disruptions in higher education mainly focused on how individual university or staff member managed the unpredictable changes and adapted to online learning to maintain ongoing education delivery (e.g. Chan, 2003; Feast \& Bretag, 2005; McNaught, 2004; Palloff \& Pratt, 2011; Wong, 2004). Students' perspective is relatively under-reported in the literature.

Looking into students' experience, it is found that online learning brought about both positive and negative impacts on them. On one hand, students reckoned that the reliance on writing as the primary mode of communication in online learning encouraged them to think more deeply compared with verbal responses (Hrastinski et al., 2010). Public display of posts also made them write more carefully and seeing others' posts allowed them to continually reflect on the course materials (Robinson $\&$ Hullinger, 2008). On the other hand, this mode of communication has also posed a challenge to students who might not have good writing skills to express themselves and they even felt that they were forced to participate, leading to minimal responses 
(Arend, 2009). Since students could work whenever and wherever they desire, this has also caused a delay in response which is a challenge to students particularly when interacting with each other in asynchronous activities (Koskey \& Benson, 2017). This issue has also been reported in teacher-student interaction (CacheroGonzalez et al., 2019; Vonderwell, 2003) and this might adversely affect students' satisfaction and learning outcomes when they valued prompt feedback from instructors the most (Eom et al., 2006; King, 2014).

While students might have benefited from the flexibility, independence and convenience brought by online learning, the student-centredness in the learning process necessarily requires students' increased responsibility for learning in that they are expected to be self-regulated, self-motivated, and self-disciplined (Kemp \& Grieve, 2014; Northrup, 2002). Students may therefore adopt various self-regulated learning (SRL) strategies including the use of imagery, note-taking, information seeking and attention focusing strategies (Adam et al., 2017). However, studies on SRL were largely conducted in the context of regular online environment. To what extent these strategies are useful for students in emergency teaching during a pandemic has not been examined, which forms one of the research objectives in this study.

\section{Online learning under COVID-19}

The outbreak of COVID-19 offers an opportunity for revisiting and examining the essential conditions for online learning, as prior experiences with emergency teaching and online teaching do not seem to have sufficiently prepared higher education institutions for it. What makes the study of online learning under COVID-19 especially worth studying is its suddenness which compels all parties to engage in it without a choice. Such context is different from the previous studies which were mostly conducted when an online course was offered on a voluntary basis or it was made compulsory for only a certain number of students (see Cachero-Gonzalez et al., 2019). There are differences in the scale and mode of participation in participants between the previous and current research. Such differences may arguably present impacts on students' expectations of online learning and thus this warrants a thorough investigation of their experience and needs during this difficult time.

The emerging research on online learning under COVID-19 has predominantly focused on examining teachers' challenges in online teaching and individual institutions' adaptations to the online environment (e.g. Bao, 2020; Basilaia \& Kvavadze, 2020; Crawford et al., 2020; Moorhouse, 2020). Students' perspective, similar to the existing research on online learning, is relatively under addressed. The scant literature on students' learning experiences during COVID-19 have indicated how students were challenged by the increased workload, lack of equipment, undesirable study environment, financial distress, and inadequate social connectedness in their online learning (Adnan, 2020; Aristovnik et al., 2020; Amir et al., 2020; Cao et al., 2020; Lederer et al., 2021). In one way or another, these studies have revealed how students were generally unable to cope with online learning (see Amir et al., 2020). Yet, the aforementioned question of whether students are able to use their own (selfregulated learning) strategies to cope with online learning is still unexamined. There 
is a need to look into this because it will allow teachers to deploy corresponding measures to facilitate their strategies and learning, helping them become independent and motivated learners, a quality that is much needed in online learning these days.

Hong Kong is a useful site for the examination of online learning during COVID19. Firstly, online learning in Hong Kong started a few months ahead of other countries due to a social movement at the end of 2019, followed by the outbreak of COVID-19. The relatively longer experience with online learning may allow students to have reflective comments on the situation. Secondly, digitally advanced countries are also facing challenges in offering online education to their students (Havergal, 2020; Zhong, 2020). Given Hong Kong's rapid development of technology and wide coverage of broadbands in most families, Hong Kong can be a useful reference for other developed countries or places that struggle to provide online learning (e.g. Lee \& Wang, 2019).

\section{Research questions}

The literature above demonstrates the following research gaps: (1) more research on online learning under COVID-19 is needed as the impacts of the sudden and compulsory change of study mode on students have yet to be fully captured, (2) students' voice is relatively underrepresented in the growing literature of online learning under COVID-19, especially concerning their use of learning strategies, and (3) there is yet to be any systematic study on the topic in the context of Hong Kong despite its potential usefulness as a reference. In order to address these gaps, this study will use a bottom-up approach to examine students' overall experience with online learning during the COVID-19 pandemic through a questionnaire and seek to answer the following three questions:

RQ 1: What challenges did students face in their online learning?

RQ 2: What kind of support did students need in their online learning?

RQ 3: What strategies did students use to overcome the challenges in their online learning?

\section{Methodology}

\subsection{Participants}

A total of 145 higher education students $($ Male $=55$; Female $=90)$ aged between 18 to 29 years old (Age $15-19=68 ; 20-25=67$; others $=10$ ) were recruited from two higher education institutions in Hong Kong. The inclusion criteria were: (1) the students were from a higher education setting in Hong Kong, and (2) had sufficient experience in this sudden shift from face-to-face learning to full online learning (for nearly one complete semester) during the pandemic outbreak. These participants were from various disciplines such as business, arts and medicine. The three 
most used e-platforms were Zoom $(n=80)$, Microsoft Teams $(n=78)$ and Moodle $(n=56)$. The majority of the participants $(n=74)$ spent 10 to $<20 \mathrm{~h}$ per week on these e-platforms for online learning during the outbreak of COVID-19.

\subsection{Instrument for data collection}

A web-link questionnaire was used as an instrument for data collection. There were two sections: Section 1 consisted of open-ended questions revolving around three aspects: challenges students had, support they needed and strategies they used to overcome the challenges and cope with this sudden shift of learning mode. These questions were designed to elicit free-text responses. To elicit more responses, clear instructions and examples were given to show the participants the details required in their responses. This strategy ensures that "thick descriptions" are given to support deeper forms of analysis (O’Cathain \& Thomas, 2004). Section 2 was about the participants' background information including types of online platforms used and time spent on these platforms. The design of the questionnaire was informed by the authors' first-hand experience, informal conversations with students and discussions with colleagues so as to ensure that the questionnaire was suitable for the study context and participants.

\subsection{Procedures}

Data were collected from April 2020 to June 2020 (8 weeks in total) when this firsttime full online learning experience under this sudden shift was still 'fresh' among students. Convenience sampling was adopted as finding and approaching participants were very difficult during the pandemic. Prior to the data collection, ethical approval for this study was sought and obtained from the authors' institutions. Students who took or are currently studying the courses the authors taught were invited by the authors to participate in an online questionnaire. A link of the questionnaire was sent to them through the e-learning platforms (mainly Zoom, Microsoft Teams, and email). Using e-survey could increase the accuracy of data collection as respondents could not move on to the next question or section until they accurately entered a particular answer. This also avoids missing data and errors in data cleaning. The response rate was over $60 \%$. All respondents were informed of the details of this study prior to their consents by checking the box that they understood and agreed to participate in this survey. No personal details of respondents were retained by the research team.

\subsection{Data analysis}

The students' responses were analysed using thematic analysis. We chose this approach because it is useful for summarising key features and generating unanticipated insights and the qualitative analyses produced are suited to informing policy development (Braun \& Clarke, 2006). We followed the six phases proposed by Braun and Clarke (2006) which consist of: 
1. Familiarizing oneself with the data

2. Generating initial codes

3. Searching for themes

4. Reviewing themes

5. Defining and naming themes and

6. Producing the report.

In phase one, we read students' responses several times and make notes about what were interesting or relevant to our research questions. Keeping research questions in mind while coding could "avoid a very large amount of codes" and "provide a context to create categories of codes" (Belotto, 2018, p.2625). We discussed our notes and developed some preliminary ideas about the codes. In phase two, we conducted a more formal coding process. We worked on the coding separately and used open coding instead of imposing the pre-existing codes on our data. We then compared, discussed and modified our codes during this process. While coding words and sentences that conveyed similar meanings, Braun and Clarke (2006) suggested that the context and the primary function of the content should also be taken into consideration as a word or sentence could carry more than one meaning. Codes were modified to avoid semantic duplication and limit ambiguity. In phase three, we collated codes featuring similar contents into initial themes. These themes described the most prevalent patterns emerged from the data relevant to the research questions. In phase four, we reviewed, modified and developed the themes by following the guided questions suggested by Maguire and Delahunt (2017). The major revisions we made included combining themes when there was an overlap and creating a new broader theme where themes were made as subthemes to ensure that each theme and subtheme was coherent and distinctive. In phase five, we refined and defined the themes and subthemes to ensure their distinctiveness and clear relationships between them. There were multiple rounds of coding, categorisation of codes into themes and refinement of themes and subthemes before the final phase. In phase six, we selected the most representative examples of these themes and subthemes and generated the final analysis of these extracts in relation to the research questions.

Various measures were taken to ensure the reliability and validity of the data analysis. A number of interrater reliability tests and discussions were conducted throughout this process. Five trained research members (including the two authors) were involved and worked separately to analyse the data manually to ensure credibility and dependability of this process. Any disagreements were discussed and resolved by the two authors. Assistance was sought from a third member when necessary. The agreement between coders was measured using Miles and Huberman's (1994) formula (i.e. Reliability = number of agreements/ total number of agreements + number of disagreements). Agreement ranging from $84 \%$ to $95 \%$ was reached between coders, indicating that the codes and categories were reliable (Saldaña, 2009). 


\section{Results}

\subsection{What challenges did students face in their online learning?}

Six main themes and eleven subthemes were identified for the challenges students faced in completing online learning (Table 1).

Table 1 Students' challenges in completing online learning

\begin{tabular}{|c|c|c|}
\hline Main Theme & Subtheme & Definition \\
\hline $\begin{array}{l}\text { Essential face-to- } \\
\text { face classes }\end{array}$ & Requiring physical presence in class & $\begin{array}{l}\text { Students find it rather impossible to } \\
\text { complete the work at home when } \\
\text { it involves practicum or laboratory } \\
\text { equipment }\end{array}$ \\
\hline \multirow[t]{2}{*}{ IT problems } & Lacking electronic devices & $\begin{array}{l}\text { Students do not have the appropri- } \\
\text { ate or enough electronic device for } \\
\text { online learning }\end{array}$ \\
\hline & Experiencing unstable connections & $\begin{array}{l}\text { Students experience connection prob- } \\
\text { lems with e-learning platforms }\end{array}$ \\
\hline \multirow[t]{3}{*}{ Concentration } & Studying in an undesirable environment & $\begin{array}{l}\text { Students find their home an undesir- } \\
\text { able and distracting place for online } \\
\text { learning }\end{array}$ \\
\hline & Having e-resources readily available & $\begin{array}{l}\text { Students find that they would delay } \\
\text { their studies when e-resources are } \\
\text { readily available }\end{array}$ \\
\hline & Experiencing physical discomfort & $\begin{array}{l}\text { Students find it physically uncom- } \\
\text { fortable to have online learning on } \\
\text { electronic devices after a certain } \\
\text { period of time }\end{array}$ \\
\hline \multirow[t]{2}{*}{ Interactions } & Lacking student-to-student interaction & $\begin{array}{l}\text { Students find it hard to make friends } \\
\text { and engage in discussions with } \\
\text { peers in online learning }\end{array}$ \\
\hline & Lacking student-to-teacher interaction & $\begin{array}{l}\text { Students find it hard to consult their } \\
\text { teachers and receive immediate } \\
\text { feedback in online learning }\end{array}$ \\
\hline \multirow[t]{2}{*}{ Time management } & Receiving unclear assignment instructions & $\begin{array}{l}\text { Students are troubled by a lack of } \\
\text { clear instructions for assignment } \\
\text { deadlines }\end{array}$ \\
\hline & Releasing lecture videos in one go & $\begin{array}{l}\text { Students find it difficult to catch up } \\
\text { with the course progress when some } \\
\text { teachers would only upload the } \\
\text { lecture videos in one go at a certain } \\
\text { point }\end{array}$ \\
\hline Assessment method & Doubting the fairness of online tests & $\begin{array}{l}\text { Students are concerned about the fair- } \\
\text { ness of online tests as cheating and } \\
\text { plagiarism are likely to arise }\end{array}$ \\
\hline
\end{tabular}




\subsubsection{Essential face-to-face classes}

Students expressed that there were classes that could not be replaced by online learning and had to be done face-to-face in school, for example, medical training where demonstrations and hands-on practice are important:

"Some modules need face to face learning, e.g. diagnose training. I can't do it at home at all. I need demonstration and do it myself." (S41\#)

Another example of this is laboratory work which requires the use of certain equipment that could only be provided by the school. Yet, a choice at times had to be made between laboratory work and online classes because while the former could only be completed at school, the latter would be better conducted at home from students' perspective:

"I have thought [about studying on] main campus [and] then go [to] lab afterward. However, for zoom, it is not convenient to do [online lessons] outside, so I need to [go] back home. As result, no lab can be done." (S50\#)

Therefore, it was challenging for them to handle online learning when such special classes were involved in their programmes.

\subsubsection{IT problems}

Experiencing unstable internet connections was a problem that students countered in online learning which may affect the lesson quality:

"Technical problem such as internet connection, download problem, upload problem, Zoom connection etc." (S39\#)

"Sometimes the wifi is weak so some words are not [heard] clearly." (S77\#)

Yet, it was not only the internet connection that presented a challenge to students' online learning, the hardware needed for online lessons was also another technical issue in question. Students lacked the appropriate electronic device for online learning in which a microphone was often found absent in their computer.

"Without microphone for my computer. I can't ask questions. And my phone isn't ok for lecture." (S22\#)

Similar unpleasant experience of using mobiles for online learning was also shared by another student:

"I have [to] share my computer with 3 brothers and my phone [lags] for lessons. My lessons always clash with [theirs].” (S31\#)

In fact, the collected comments pointed to computers as the preferred device for online learning but resource usage or sharing could be problematic for certain households where several family members engaging in online learning at the same time. 


\subsubsection{Concentration}

Students expressed having troubles concentrating on online learning when studying at home, an environment that was deemed undesirable. Specifically, it was too noisy and crowdy for studying:

"I can't focus because environment [is] noisy. Too many people in home and they keep talking when I'm having class." (S101\#)

"My home is too small and I can hear my mum, TV, street noise...I just can't focus on the lecture" (S69\#)

Due to limited space, students had to endure the noise by their family members during online learning but as the above comments suggested, they could barely stay focused in class. In this regard, the space problem has brought certain impacts to students' online learning.

What also challenged students' concentration was the physical discomfort resulted from having online learning for too long. As noted in Table 1, around half of the students had to spent at least 10-20 h per week on e-learning. Some students said they had experienced eye soreness while some overall physical tiredness. For instance, two students shared:

"Can't focus, my eyes so tired when watching the screen" (S69\#)

"My body health, always focusing on the computer make my eyes feel painful and I can't concentrate [in] class" (S71\#)

One interesting source of challenge to students' concentration came from the e-resources available to them. When they were readily available online, students found it to be a reason for them to concentrate less in class or even delay their study because they could self study the materials later on:

"The more complete [e-resource] recording gives me a feeling that I can check it later so it is not a must to stay focused." (S55\#)

The flexibility offered by e-sources therefore somewhat demands students to be selfdisciplined, as one student observed:

"It requires extra self-discipline as the learning has become more flexible and I don't have to study right away. I get to access the lecture recording anytime if it is not a live lesson. Hence, I have to be stricter to myself in finishing the online learning instead of accumulating all the recordings to finish at the very last moment before any test." (S58\#)

\subsubsection{Interactions}

Limited student-to-student interaction was identified from the comments as a problem in online learning. Students found it hard to make friends in online classes and they were not comfortable to have discussions online. This may be partly because 
students could not see or even hear each other on e-learning platforms when the microphone or camera was not switched on. As one student shared:

"Discussing with my classmates is less comfortable in online learning than face-to-face learning. I can't see them. I don't know their reaction when I speak. So I don't speak." (S44\#)

The absence of image and sound from peers may discourage students from participating in online discussions.

Apart from this, student-to-teacher interaction was also found to be problematic in online learning. In particular, students expressed having difficulties in engaging in immediate interactions with or receiving immediate feedback from teachers. Oftentimes, emails had to be used for follow-up communication but it necessarily took up more of students' time:

"When I got some problems, I could not ask teachers immediately. I need to email the teacher and wait for his answer." (S9\#)

"Asking question[s] after class through email require[s] much more time." (S81\#)

Yet, students did not seem to be comfortable and confident in written communication and the clarity of the written message in emails became a concern for them:

"Also hard to have [an] immediate interaction with teachers. Sometime[s] [it] is hard to transmit the message clearly in email." (S55\#)

In contrast, students valued physical interactions in face-to-face learning and one student suggested that the feedback from face-to-face teaching is more "solid":

"It was a bit hard to adopt at first as I have rarely done online learning before and I am used to face-to-face learning, for example, like having a class physically instead of virtually. I feel like face-to-face learning is more solid in terms of receiving feedback from lecturers or tutors given by the physical interaction." (S13\#)

\subsubsection{Time management}

Students were concerned about time management in their online learning. They were particularly troubled by assignment deadlines because the instructions for them were not very clear. Students reckoned that the deadlines were buried somewhere and were not announced clearly and consistently using the same means. One student echoed with this in his/her experience:

"Some courses require me to watch the lecture videos and to finish some quizzes. However, the deadlines are not clearly stated on [M]oodle. Also, the schedule of some courses keep[s] changing and updating but the teachers may not inform me. That makes [it] very hard to follow." (S17\#) 
Students drew attention to the importance of announcing deadlines in class instead of scattering them over different portals and this can be seen from the following comment:

"I am so worried that I would miss any of the deadlines as some of them are not announced during lessons. At school, teacher would confirm the deadlines in class and I don't have to worry." (S93\#)

Another time management issue was found to be related to the availability of lecture videos. It was difficult for students to catch up with the course progress when some teachers would only upload the lecture videos in one go at a certain point. For learning or revision purposes, this may not be ideal for students:

"[The challenge is] to keep up with the learning schedule, as the teachers may upload their videos all on the same day, which makes me feel a bit overwhelmed." (S73\#)

Failure to properly handle the above time management issues may place psychological burdens on students. In fact, there was a student who was so stressed by time management in online learning that different negative feelings were brought out in him/ her including self-hatred and sorrow:

"I have lost control on my time management. I finished and submitted all my assignments only right before the deadline (i.e. one minute or less). I hate myself. I am more motivated at school than my home. I hate studying and revising at home. I just cannot focus on study at home. I'm sorry.” (S21\#)

\subsubsection{Assessment method}

Fairness of online tests was brought into concern for students having online learning. Students suggested that since online tests were administered through e-learning portals and completed at home, there was a higher chance of students committing plagiarism or cheating. It may not be fair to everyone.

"One of the areas that I would like to address on is the concern of the fairness about online assessments. With online exam or test, students may be communicating or discussing with others while performing the test to gain an extra advantage on it, which is totally unfair to students who have worked extra harder as they would probably receive the same grade at the end." (S121\#)

\subsection{What kind of support did students need in their online learning?}

Five themes and seven subthemes arose from the comments when students were asked to suggest the kind of support they would need to complete online learning (Table 2). 
Table 2 Students' perceived needs in completing online learning

\begin{tabular}{|c|c|c|}
\hline Main Theme & Subtheme & Definition \\
\hline \multirow[t]{3}{*}{$\begin{array}{l}\text { Teaching delivery } \\
\text { method }\end{array}$} & $\begin{array}{l}\text { Having more examples } \\
\text { from teachers }\end{array}$ & $\begin{array}{l}\text { Students would like to have more examples for } \\
\text { course materials from teachers }\end{array}$ \\
\hline & Recording every lecture & $\begin{array}{l}\text { Students would like every lecture to be video } \\
\text { recorded and uploaded to the e-learning platform } \\
\text { for their study }\end{array}$ \\
\hline & Having more quizzes & $\begin{array}{l}\text { Students would like to have more regular quizzes to } \\
\text { make them keep track of class schedule }\end{array}$ \\
\hline Interaction & $\begin{array}{r}\text { Having more interactions } \\
\text { with peers and teachers }\end{array}$ & $\begin{array}{l}\text { Students would like to more interactions with peers } \\
\text { and teachers through different functions of the } \\
\text { e-learning platforms }\end{array}$ \\
\hline Teachers' feedback & $\begin{array}{l}\text { Receiving feedback from } \\
\text { teachers }\end{array}$ & $\begin{array}{l}\text { Students would like to have detailed and timely } \\
\text { feedback from teachers }\end{array}$ \\
\hline IT support & $\begin{array}{l}\text { Having navigation } \\
\text { guidelines }\end{array}$ & $\begin{array}{l}\text { Students would like to have step-by-step guideline } \\
\text { to help them navigate the e-learning platforms }\end{array}$ \\
\hline Course arrangement & $\begin{array}{l}\text { Having clear instructions } \\
\text { about course arrange- } \\
\text { ment }\end{array}$ & $\begin{array}{l}\text { Students would like to be given clear instructions } \\
\text { about the course arrangement by teachers }\end{array}$ \\
\hline
\end{tabular}

\subsubsection{Teaching delivery method}

Students identified several ways teachers could help them with online learning. One is to give more examples to illustrate the concepts in class. They found it difficult to understand the course materials when teachers were going through them too fast and did not explain them in detail with more examples.

"More examples from my teacher. He's teaching too fast and [does] not know when to stop. Because he can't see us?" (S31\#)

Looking into this comment, it suggests that the fast teaching pace may be related to the limited interaction in online learning. The teacher may not be able to gauge the learning progress due to the absence of nonverbal cues from students who may not have show their face on camera or speak up through microphone.

Another thing that teachers can do to support online learning is to have more regular quizzes to make students keep track of the class schedule. Students reckoned that it can motivate them to focus in class and study more on their own.

"Small quizzes for monitoring learning progress and consultation sessions for both online learning and assessments." (S27\#)

Apart from class teaching, students expressed that they would need support after class too. They would like every lecture to be video recorded and uploaded to the e-learning platform for their study.

"If you can provide videos for each lecture, it will be better. After the semester, the videos can be deleted."(S97\#)

It seems that lecture videos are an important learning source for students in online learning. 


\subsubsection{Interaction}

More interactions with peers and teachers were considered necessary for online learning by students. In fact, they hope that peer interactions can be increased so that there will be more peer support to help each other finish online learning, for example, reminding one another of assignment deadlines and discussing course content. A way to achieve this is to exploit the functions of e-learning platforms including chatrooms and forums, as suggested in the following comment:

"I would need peer support to facilitate my completion of online learning and assessments. For example, discussion through group chat in Zoom, or Moodle Forum.” (S66\#)

Equally important are the interactions with teachers. To be specific, they would like to have more individual consultations with teachers in which both parties can engage in a dialogue to go through the questions students have. Consultations through phones and e-learning platforms like Zoom and MS Teams have been suggested as comfortable portals for students.

"More individual consultations with teachers. Phone would also be fine. Just no emails [please]" (S2\#)

\subsubsection{Teachers' feedback}

There is a more specific form of support students want from teachers - more feedback. It is not just the quantity that matters to students but the manner in which the feedback is delivered is also of paramount importance. Two essential elements concerning teachers' feedback were mentioned in the comments - it should be timely and detailed.

"More detailed and explicit feedback on the assignments." (S5\#)

"I need quick feedback from professors or tutors from e-mail. Don't reply [to] me after a week or two. For some professors, please at least let me know that you will reply." (S66\#)

The second comment further suggests that students would also like to know when to expect the teacher to be returning the feedback.

\subsubsection{IT support}

The only IT support requested by students concerns the navigation of e-learning platforms. Students expect that a step-by-step guide be made available to help them navigate the e-learning platforms, for example what functions are present on such platforms and where they can locate the files.

"I do need [an] instruction telling me how to deal with Moodle (I usually have no idea where to find the documents I need or where to submit). And some introduction to the Zoom functions will be nice too." (S40\#) 


\subsubsection{Course arrangement}

Students ask that teachers make a clearer instruction about the course arrangement. In the comments, students reiterated the importance of how the instruction should be announced systematically and consistently using the same method. One student suggested that:

"I think teachers would be playing a very vital role in updating students the latest course arrangement, like the course component and assessment format systematically whenever there is a change to make sure everyone has been well-informed of the latest announcement. Don't tell me one deadline in email and then another in Moodle." (S9\#)

This implies that teachers should not announce deadlines or course information in various places. Scattered information, as students expressed in the previous section on the challenges of online learning, may present difficulties to their time management and even place psychological burdens on them (i.e. the fear of missing deadlines).

\subsection{What strategies did students use to overcome the challenges in their online learning?}

Six themes and ten subthemes emerged from the students' comments concerning the strategies they used to tackle the encountered challenges in online learning (Table 3).

Table 3 Students' strategies in completing online learning

\begin{tabular}{|c|c|c|}
\hline Main Theme & Subtheme & Definition \\
\hline Passive approach & Giving up & $\begin{array}{l}\text { Students give up on taking any measure to over } \\
\text { challenges }\end{array}$ \\
\hline Interaction strategies & Interacting with peers and teachers & $\begin{array}{l}\text { Students actively participate in class activities and } \\
\text { interact with peers and teachers in class and out } \\
\text { of class }\end{array}$ \\
\hline \multirow[t]{2}{*}{ IT skills } & $\begin{array}{l}\text { Preparing an extra electronic device } \\
\text { for class }\end{array}$ & $\begin{array}{l}\text { Students keep an extra electronic device ready } \\
\text { for online learning in case of internet or device } \\
\text { malfunction }\end{array}$ \\
\hline & Running some tests before class & $\begin{array}{l}\text { Students test the internet connection, functions of } \\
\text { software and devices before class (with friends at } \\
\text { times) }\end{array}$ \\
\hline \multirow[t]{3}{*}{$\begin{array}{l}\text { Self-regulated learning } \\
\text { strategies }\end{array}$} & $\begin{array}{l}\text { Reading up on relevant learning } \\
\text { materials }\end{array}$ & $\begin{array}{l}\text { Students prepare for class by reading up on relevant } \\
\text { learning materials }\end{array}$ \\
\hline & Studying recorded videos & Students review or study the recorded lecture videos \\
\hline & Managing time & $\begin{array}{l}\text { Students manage their assessment deadlines and } \\
\text { workload with different tools }\end{array}$ \\
\hline $\begin{array}{l}\text { Alternative learning } \\
\text { environment }\end{array}$ & $\begin{array}{l}\text { Seeking a desirable learning } \\
\text { environment }\end{array}$ & Students go to a desirable place for online learning \\
\hline \multirow[t]{2}{*}{$\begin{array}{l}\text { Physical strength } \\
\text { improvement }\end{array}$} & Taking a nap & $\begin{array}{l}\text { Students take a nap to recover the strength needed for } \\
\text { online learning }\end{array}$ \\
\hline & $\begin{array}{l}\text { Consuming energy-boosting } \\
\text { products }\end{array}$ & $\begin{array}{l}\text { Students consume certain energy-boosting foods or } \\
\text { drinks to stay awake for online learning }\end{array}$ \\
\hline
\end{tabular}




\subsubsection{Passive approach}

Certain students were feeling a bit helpless or nonchalant when they were facing difficulties in online learning. Giving up was one coping mechanism for them:

"Let it be" (S96\#)

A slightly less negative reaction for some was to wish that online learning would not take place in the coming academic year:

"No idea to overcome them. Just hope next [semester] no more online [learning]." (S8\#)

In any case, this rather passive approach highlights how more support may need to be offered to students to assist them in their online learning.

\subsubsection{Interaction strategies}

In contrast to the above approach, some students were found to adopt a more positive and proactive approach towards online learning. They would maximize their interactions with peers and teachers by actively taking part in class activities:

"Forcing myself to participate in the group discussion. After a while, the situation may become better." (S77\#)

Making use of features of e-learning platforms was also a way to enhance interactions with teachers and peers, for example using annotation function in Zoom for collaborative work and using the chatroom function for asking questions. One student explained the rationale of using chatrooms:

"I will try to ask more questions through the chatting room when I have some-

thing unclear. It's faster and better than using email." (S81\#)

Yet, this is not to say that the traditional communication method of using emails has become obsolete. In fact, it seemed to remain useful for consultation to students:

"I try to email my tutors if I am confused with certain concept though it is time-consuming." (S53\#)

\subsubsection{IT skills}

Having online learning invariably involves some technical problems. Students focused on both hardware and software issues when devising the corresponding strategies. For the hardware issue, students said they would mostly use computers for online learning but they would keep an extra electronic device ready in case of internet or device malfunction:

"I would have another computer/device ready just in case my usual laptop breaks down or have technical difficulties." 
As to the software issue, they reckoned that the e-learning platform might not function properly at times and before any presentations, they would have a dry run among themselves just to test the platform and internet stability.

"Test the function of Zoom with friends before presentation. Test the wifi too. Just prepare more before class and tell teacher if they are [working]."

\subsubsection{Self-regulated learning strategies}

Students deployed various self-regulated learning strategies to help themselves catch up with their study progress. Doing more class preparation by searching for and reading up on relevant learning materials was one approach.

"Previewed the learning materials and did the homework. Googled for more information myself." (S58\#)

Another strategy was to make use of the recorded videos for study and revision. Students said they could repeatedly watch the videos to make sense of the content and the videos would give them a reference for peer discussion. Furthermore, thanks to the properties of video, students were able to engage in a different note-taking pattern - pausing and rewinding to the important part of the video for jotting notes:

"I can pause the video then jot down the key points if it is not online live lesson. This may [be] hard to achieve in face to face lessons." (S89\#)

A final strategy that students used centered on time management. Students found it important to create a schedule and prioritize the tasks so as to have a better planning for learning progress.

"[Strategically] prioritizing subjects, work on [them] early in morning/late at night. I will write a schedule to plan what lecture videos to watch for each day" (S13\#)

When creating a schedule, students resorted to different types of apps to help them keep track of deadlines including calendar, checklist and reminder apps, as one student shared:

"Use of google calendar, "Notes" app and "Reminders" app to keep [reminding] me [of] deadlines. Use time-recording APP to keep track of what I am doing [every day]" (S81\#)

\subsubsection{Alternative learning environment}

Searching for an alternative desirable learning environment was a notable theme in students' tactics of handling online learning. There were several recurring elements in the description of such an environment i.e. quietness, good internet 
connection and enough working space. Interestingly, most students gave the same example of it - school:

"Trying to find a place that can have a better internet connection. School is probably the best." (S101\#)

\subsubsection{Physical strength improvement}

Students regarded online learning as an activity that requires a certain level of energy and concentration, so they used different ways to keep up their energy level. One commonly mentioned method was to take a quick nap to recover the strength before class:

"I try to have a short-time nap before I join in an online class. Or else I might fall asleep." (S7\#)

Another method was to consume some energy-boosting products to stay awake for online learning. One student implied that this strategy is more appropriate to be used in online learning as eating may not be deemed appropriate in a face-toface learning environment:

"I [prefer] to eat something like bananas to help me concentrate. This might be strange, but it works. And I cannot eat anything in face-to-face learning of course." (S11\#)

Students listed some specific energy-boosting products that would help their concentration in which caffeinated drinks like coffee and tea were often mentioned:

"Have a cup of green tea to enhance my focus." (S42\#)

\section{Discussion}

The following discussion will examine various measures that can be used to facilitate students' online learning by looking into how some of the challenges (i.e. concentration, IT problems and interactions) might deserve our attention, how some self-regulated learning strategies (i.e. using time management apps and taking notes based on videos) can be useful for online learning and how some of the areas (i.e. feedback and course clarity) might require some more support for students.

\subsection{What challenges did students face in their online learning?}

Consistent with the previous research, students in our study found it difficult to concentrate on online learning (Tsai, 2009). Yet, the source of distraction was not so much about the available entertainment on computers e.g. music (Tsai, 2009). Instead, it seems to have to do with a socio-economic issue in Hong Kong - space 
problem. Students said that they were easily distracted by the study environment in their home which was described as noisy and crowded with people. This space problem comes as no surprise when Hong Kong was ranked the most expensive housing market in the world for 9 consecutive years in 2019 (Liu, 2019). It would take 21 years for one to save enough money to buy an apartment in Hong Kong (Liu, 2019) and $78 \%$ of the Hong Kong people aged from 18 to 35 years were found to be still living with their parents (Li, 2014). Given the limited space in Hong Kong, the accompanying noise problem seems rather unavoidable and it may remain a challenging issue to students' online learning when schools maintain limited opening hours and impose access restrictions on students under the impacts of COVID-19.

There were some IT problems that posed certain challenges to students in their online learning. An earlier study revealed that technical problems were not only the primary challenge to student's online learning but the also major determinant on whether students were satisfied with it or not (Song et al., 2004). It is therefore important to identify the specific IT problems so that corresponding measures can be deployed. Our study has discovered that unstable network and device problems were two major issues. Concerning the latter, it is not just about whether one has the appropriate equipment (i.e. a computer with a microphone) but also whether one has enough equipment for online learning or not. Some students in our comments had to share their electronic device with their siblings for online learning and may not have a proper device for class. In other words, access to computers could be problematic for certain students. A survey by Society for Community Organization (2020) indeed shows that among 582 low-income students, $70 \%$ of them do not have computers and $28 \%$ even do not have broadband internet. This number could be interpreted better under the huge wealth gap between the rich and the poor in Hong Kong where the Gini Coefficient was 0.539 (when 0 means equality) in 2016 (Census and Statistics Department Hong Kong Special Administrative Region Government, 2017). University computer loaning programme is a welcomed approach to help these students with their equipment problem, but most of these programmes in Hong Kong restrict the computers to on-campus use only or the loan time to only a few hours (see The Hong Kong Polytechnic University, n.d.; The University of Hong Kong, 2019). It clearly does not address the needs of this student population who requires a computer for online learning for a relatively long time under COVID-19. Therefore, universities should look into the possibilities of relaxing the loan terms of their computers to students whenever necessary. This also responds to the call for research on how institutions can look for ways to minimize students' distress arising the socio-economic aspects of their lives during COVID-19 (see Aristovnik et al., 2020).

Even when students could access online learning, student-to-student interaction was found to be rather limited. Students found it difficult to connect with their peers socially and academically. This is also congruent with earlier studies that suggest how the lack of social interaction was a barrier to online learning (Muilenburg \& Berge, 2005). Student-to-student interaction is a significant factor that affects students' level of learning and satisfaction with online learning (Sher, 2009). One way to improve it is to use videoconferencing or chatroom function to engage students in discussions in synchronous online teaching (Banna et al., 2015). The students in the 
comments shared the same view that using chatrooms could potentially help promote interactions with peers and teachers and that they adopted it as one of their learning strategies.

In line with previous studies, our findings also found that limited student-toteacher interactions continued to challenge students' online learning (Bullen, 1998; Wang \& Newlin, 2001). In particular, they could not interact with their teachers much and receive immediate feedback. To facilitate learning, students had to resort to emails to interact with teachers even though they did not seem to favor this portal. This in a way confirms how student-to-teacher interaction (LaPointe \& Reisetter, 2008) and teachers' feedback (King, 2014) are both valued components of online learning. Teachers should therefore give students an impression that they are reachable for consultation by providing the appropriate means (Lee et al., 2011). Our study has identified written communication such as emails as a less favorable means for Hong Kong students because it is difficult for them to express themselves clearly through writing. The difficulty may be related to the fact that English is culturally used as the language for communication in schools even though it is only a second language to most of our students. This view is also shared by other Chinese students (Tu, 2001). In our study, our students would like to have more individual consultations through audio communication like mobile phones and in this connection, individual teleconferencing meetings through e-learning platforms like Zoom would also be a more comfortable means for students. Furthermore, similar to consultations after face-to-face classes, this more direct form of communication will also allow students to speak more freely in a language they want like the local tongue.

It should be noted that the suggested measures above (i.e. using chatrooms and audio meetings) all center on the element of creating a dialogue between the involved parties. This is an important step to minimize the transactional distance which is viewed as "a space of potential misunderstanding between the inputs of instructor and those of the learner" (Moore, 1993, p.20). The transactional distance is mainly determined by three elements - course structure, dialogue and learner autonomy (Moore \& Kearsley, 2012). The greater the transactional distance, the more chances the learners have to exercise autonomy (Moore, 2007). In the current situation where students were hoping to participate in the online courses more, measures have to be devised to decrease the transactional distance and increasing dialogue is an effective approach (Saba, 2007). Indeed, through the interactive communication in chatrooms and audio meetings, students will engage in the process of sharing and negotiating meaning with teachers back and forth, and such dynamic process called feedback loop will contribute to students' learning (Saba, 2007). From our students' perspective, such kind of communication is much desired, which also reveals how transactional distance should be considered when designing help for students.

\subsection{What kind of support did students need in their online learning?}

Feedback has been frequently highlighted by our students as an area in need of help. In particular, the students would like to have more feedback from teachers but it should be delivered in a timely and detailed manner. Timely feedback was indeed 
reported as highly valued by students (King, 2014; Northrup, 2009) and also significant for students' learning outcomes (Eom et al., 2006) and perceived quality of online learning (Ruey, 2010). While it is hard to define precisely what "timely" feedback should be like, a student's comment revealed that taking a week to reply to an email was probably not ideal. Northrup (2009) has suggested that teachers try to give some kind of feedback to students at least twice per week. This could be a useful tip for teachers when handling feedback but a more important message that can be drawn from our students' experience is that teachers should set up expectations with students on the turnaround time of emails/ assignments. A better communication between both parties will benefit their management of the course.

Course clarity is another area where more support is need. Students were confused about course arrangement due to scattered information across different portals (e.g. emails, e-learning system and in-class announcement). It is important that students are given clear instructions about the course, as it is one of the elements related to students' satisfaction with online learning (see Johnston et al., 2005). Earlier studies have suggested using regular in-class announcements or emails to remind students of course matters (Ko \& Rossen, 2010; Martin \& Bolliger, 2018). Yet, our study highlights that it is not only the frequency that matters, but the manner through which the instruction or announcement is made is equally important - it should be consistent and systematic. Students valued the consistency of teachers using the same portal to send them reminders, as any inconsistency might lead to students' confusion and psychological burdens of overlooking information.

\subsection{What strategies did students use to overcome the challenges in their online learning?}

It is alarming to see that some students seemed to be stranded in online learning and gave up on taking any measures to tackle their challenges in online learning. Nevertheless, we have also found how some other students used different SRL strategies to facilitate their learning, two of which are especially worthy of attention as they present room for teachers to find ways to enhance their effectiveness. One SRL strategy frequently used by the students was to utilize time management apps like Google calendar and to-do-list to help them prioritize tasks and follow deadlines. The rationale behind is in line what previous studies found - to maintain a time management schedule for monitoring study progress (Northrup, 2009). Time management skills as such are indeed an important and useful element for online learning (Song et al., 2004). What teachers can do is to examine the possibility of integrating the use of such apps into the course, releasing and synchronizing the course deadlines and reminders there. This suggestion also echoes with students' wish for a single portal for unified and comprehensive announcements.

Another interesting SRL strategy was to engage in note-taking based on lecture videos. This is an encouraged practice as it allows students to reflect on their learning, and if students can jot down their personal reactions to the materials, it will also strengthen their synaptic connections (see Bean, 2011; Zull, 2011). Videos can be a useful tool for students to individualize their learning at their own pace, as Moos and 
Bonde (2016) reckon "struggling students can pause and rewind the video as many times as necessary, whereas those who have developed sufficient mastery can spend less time viewing the content" (p.247). There are two ways teachers can potentially help. One is to enrich the multi-modal learning environment by creating lecture videos that incorporate pictures, texts, animation and audio. Such multimodality may cater to the needs of students with different learning styles and facilitate their learning (Sankey et al., 2010). Second is to make lecture videos for all the lessons. One observation made by the students is that all not the teachers would make lecture videos available. At least in the institutions where the authors are teaching, the current policies do not mandate that lessons be recorded as long as there are other forms of teaching support like narrated PowerPoints. However, previous research has already indicated the importance of electronic materials (e.g. e-books) in motivating students' independent learning and has thus encouraged institutions to assist their teachers in preparing the sources that are valued by students (see Shurygin \& Krasnova, 2016). Our study has contributed to this line of research by showing how lecture videos were considered essential by students. Therefore, teachers and university policy makers should examine how lecture videos may benefit students' online learning in relation to the nature of different subjects and enact relevant policies to make available e-learning materials that can help promote and facilitate students' SRL strategies.

\section{Conclusion}

Using thematic analysis, our study has systematically reviewed students' experiences with online learning under COVID-19 by identifying 7 kinds of challenges they faced, 4 types of strategies they used and 5 areas of support they needed in the process. What makes this study interesting is how it has demonstrated the impacts of emotional, technological and socio-economic factors on different aspects of student's online learning and this has presented implications to the study of online learning and emergency teaching at both theoretical and practical levels.

At the practical level, various specific suggestions have been made in relation to students' needs in online learning during the pandemic. For institutions, loosening the restrictions of the computer loan programme may be able to ease students' distress resulted from the socio-economic problems in Hong Kong; enacting policies concerning the availability of lecture videos may be able to facilitate students' independent learning to a greater extent. For teachers, announcing course information consistently with one single portal may relieve students' emotional burden of missing deadlines; providing more audio instead of written feedback may be more suitable for students in Hong Kong; integrating the use of time management apps into courses may align with students' technological needs in their SRL strategies.

At the theoretical level, it has revealed how certain linguistic and technological factors should be considered when deploying measures to help students with online learning. First of all, the need for decreasing transactional distance is indicated by our students' desires for more communication with teachers and this is preferably 
done through verbal instead of written means. One potential reason is that our students may not be fully competent in expressing themselves in writing through their second language - English. In contrast, through verbal means, they may be allowed to use the local tongue for more efficient communication. This suggests that students' linguistic needs might be a factor for gauging the effectiveness of measures based on theory of transactional distance. Secondly, students' use of time management apps and lecture videos for self learning underscores the increasing importance of the technological aspect in SRL strategies - while students make use of technology for online learning, teachers should find ways to respond to such technological needs so that the effectiveness of their SRL strategies can be maximized.

In conclusion, our study has contributed to the growing study of online learning under COVID by projecting the voice of students and highlighting their use of SRL strategies, both of which have been underrepresented in the current literature. While the existing literature seems to suggest how students were rather incapable of handling online learning through studying the involved challenges and requested support, our study has shed positive light on this by showing how students actively tried to become independent learners with their own SRL strategies. What students require are some positive responses to their needs at emotional, technological and socio-economic levels. By painting a comprehensive landscape of online learning under COVID-19 through Hong Kong students' experience, this study has indeed provided insights for teachers and university policymakers to ponder over the conditions and deploy the corresponding measures that can help optimize online learning for students in higher education at various levels.

\section{Limitations}

The study aims at observing the effects of the pandemic on online learning that was happening quickly and changing constantly. The limited resources and time available for this study have presented limitations to its sampling and data collection. In fact, not enough time was allowed for finding appropriate data for crossvalidation and thus the generalisability of these findings to other settings might be limited, as students could have different demographic characteristics and online learning experiences. In order to find out more factors that could affect students' perspectives and reduce social desirability bias, it is suggested that further studies be conducted with a larger sample size, using various research methods and taking students' demographic characteristics into account.

Our data might be limited by free-text responses and other possible data collection methods such as interviews or closed-ended questions, if used, might be able to enrich the data. However, these limitations do not detract from the significance of the study because the rich data collected were able to sufficiently answer our research questions. Each of our respondents was able to write more than 250 words disclosing their feelings and thoughts about what they had experienced in emergency online learning during this pandemic outbreak. Their responses have resulted in pages of meaningful and codable texts for our in-depth analysis. Indeed, as a starting point for exploring and unpacking students' online learning 
experiences during COVID-19, our study has provided a detailed account of their challenges, support and strategies in the process, all of which could be potentially useful for future research on emergency teaching. In particular, the highlight of students' positive SRL strategies in this study urges future research to abandon the pessimistic view of students as incapable independent learners but shift to a more optimistic approach to examine their needs. It is suggested that more research be conducted to examine the nature of their SRL strategies so that measures can be devised to help them become competent independent learners in online learning.

Acknowledgements We would like to thank Dr. Crystal Lee for her help with the survey and data collection.

Authors' contributions Matthew Yeung and Alice Yau contributed to the design of the questionnaire and data collection. They have both conducted data analysis, interpretation of results, write-up and revision of the paper.

Data availability Not applicable.

Code availability Not applicable.

Declarations

Ethics approval Ethical approval was sought from the institutions where data were collected.

Consent to participate Informed consent was obtained from all individual participants included in the study.

Consent for publication The authors affirm that human research participants provided informed consent for publication.

Competing interests Not applicable.

\section{References}

Adam, N. L., Alzahri, F. B., Cik Soh, S., Abu Bakar, N., \& Mohamad Kamal, N. A. (2017). Self-regulated learning and online learning: A systematic review. In H. Badioze Zaman, P. Robinson, A. F. Smeaton, T. K. Shih, S. Velastin, T. Terutoshi, A. Jaafar, \& N. Mohamad Ali (Eds.), Advances in visual informatics (pp. 143-154). Springer International Publishing. https://doi.org/10.1007/ 978-3-319-70010-6_14.

Adnan, M. (2020). Online learning amid the COVID-19 pandemic: Students perspectives. Journal of Pedagogical Sociology and Psychology, 1(2), 45-51. https://doi.org/10.33902/JPSP.2020261309.

Allen, I. E., \& Seaman, J. (2010). Learning on demand: Online education in the United States, 2009. Sloan Consortium.

Amir, L. R., Tanti, I., Maharani, D. A., Wimardhani, Y. S., Julia, V., Sulijaya, B., \& Puspitawati, R. (2020). Student perspective of classroom and distance learning during COVID-19 pandemic in the undergraduate dental study program Universitas Indonesia. BMC Medical Education, 20(1), 392-392. https://doi.org/10.1186/s12909-020-02312-0.

Arasaratnam-Smith, L. A., \& Northcote, M. (2017). Community in online higher education: Challenges and opportunities. Electronic Journal of e-Learning, 15(2), 188-198.

Arend, B. (2009). Encouraging critical thinking in online threaded discussions. Journal of Educators Online, 6(1), n1. 
Aristovnik, A., Keržič, D., Ravšelj, D., Tomaževič, N., \& Umek, L. (2020). Impacts of the COVID19 pandemic on life of higher education students: A global perspective. Sustainability, 12(20), 8438. https://doi.org/10.3390/su12208438.

Banna, J., Lin, M. F. G., Stewart, M., \& Fialkowski, M. K. (2015). Interaction matters: Strategies to promote engaged learning in an online introductory nutrition course. Journal of Online Learning and Teaching, 11(2), 249-261.

Bao, W. (2020). COVID-19 and online teaching in higher education: A case study of Peking University. Human Behavior and Emerging Technologies, 2(2), 113-115. https://doi.org/10.1002/hbe2. 191.

Basilaia, G., \& Kvavadze, D. (2020). Transition to online education in schools during a SARS-CoV-2 coronavirus (COVID-19) pandemic in Georgia. Pedagogical Research, 5(4), 1-9.

Bean, J. C. (2011). Engaging ideas: The professor's guide to integrating writing, critical thinking, and active learning in the classroom (2nd ed.). Jossey-Bass.

Belotto, M. J. (2018). Data analysis methods for qualitative research: Managing the challenges of coding, interrater reliability, and thematic analysis. The Qualitative Report, 23(11), 2622-2633.

Bonk, C. J., \& Kim, K. J. (2005). Future directions of blended learning in higher education and workplace learning settings. In C. J. Bonk \& C. R. Graham (Eds.), Handbook of blended learning: Global perspectives, local designs (pp. 550-568). Wiley.

Braun, V., \& Clarke, V. (2006). Using thematic analysis in psychology. Qualitative Research in Psychology, 3, 77-101.

Bullen, M. (1998). Participation and critical thinking in online university distance education. Journal of Distance Education, 13(2), 1-32.

Cacheiro-Gonzalez, M. L., Medina-Rivilla, A., Dominguez-Garrido, M. C., \& Medina-Dominguez, M. (2019). The learning platform in distance higher education: Student's perceptions. The Turkish Online Journal of Distance Education, 20(1), 71-95. https://doi.org/10.17718/tojde.522387.

Cao, W., Fang, Z., Hou, G., Han, M., Xu, X., Dong, J., \& Zheng, J. (2020). The psychological impact of the COVID-19 epidemic on college students in China. Psychiatry Research, 287, 112934. https://doi.org/10.1016/j.psychres.2020.112934.

Cauchemez, S., Ferguson, N. M., Wachtel, C., Tegnell, A., Saour, G., Duncan, B., \& Nicoll, A. (2009). Closure of schools during an influenza pandemic. The Lancet Infectious Diseases, 9(8), 473-481. https://doi.org/10.1016/S1473-3099(09)70176-8.

Census and Statistics Department, Hong Kong Special Administrative Region Government. (2017). Census and Statistics Department announces results of study on household income distribution in Hong Kong. https://www.censtatd.gov.hk/press_release/pressReleaseDetail.jsp?charsetID=1\& pressRID $=4180$.

Chan, D. W. (2003). A university's stories about teaching and learning during SARS: The narrative psychology perspective. Educational Research Journal, 18(2), 93-109.

Crawford, J., Butler-Henderson, K., Rudolph, J., \& Glowatz, M. (2020). COVID-19: 20 countries' higher education intra-period digital pedagogy responses. Journal of Applied Teaching and Learning (JALT), 3(1), 1-20. https://doi.org/10.37074/jalt.2020.3.1.7.

Denman, B. (2005). SARS and international education in China: Response, impact and repercussion. In L. Y. Bao \& J. Sun (Eds.), Zuji-Guoyuan Shinian: The way forward (pp. 100-114). China People's Public Security University Press.

Eom, S. B., Wen, H. J., \& Ashill, N. (2006). The determinants of students' perceived learning outcomes and satisfaction in university online education: An empirical investigation. Decision Sciences Journal of Innovative Education, 4(2), 215-235. https://doi.org/10.1111/j.1540-4609.2006.00114.x.

Feast, V., \& Bretag, T. (2005). Responding to crises in transnational education: New challenges for higher education. Higher Education Research \& Development, 24(1), 63-78. https://doi.org/10.1080/07294 36052000318578 .

Havergal, C. (2020). Refund students if online teaching has fallen short, say MPs. Times Higher Education. https://www.timeshighereducation.com/news/refund-students-if-online-teach ing-has-fallen-short-say-mps.

Hrastinski, S., Keller, C., \& Carlson, S. (2010). Design exemplars for synchronous e-learning: A design theory approach. Computers \& Education, 55(2), 652-662. https://doi.org/10.1016/j.compedu.2010. 02.025.

Johnston, J., Killion, J., \& Oomen, J. (2005). Student satisfaction in the virtual classroom. Internet Journal of Allied Health Sciences and Practice, 3(2), 6. 
Kauffman, H. (2015). A review of predictive factors of student success in and satisfaction with online learning. Research in Learning Technology, 23, 1-13. https://doi.org/10.3402/rlt.v23.26507.

Kemp, N., \& Grieve, R. (2014). Face-to-face or face-to-screen? Undergraduates' opinions and test performance in classroom vs. online learning. Frontiers in Psychology, 5, 1278. https://doi.org/10.3389/ fpsyg.2014.01278.

King, S. B. (2014). Graduate student perceptions of the use of online course tools to support engagement. International Journal for the Scholarship of Teaching and Learning, 8(1), 1-18. https://doi.org/10. 20429/ijsotl.2014.080105.

Ko, S., \& Rossen, S. (2010). Teaching online: A practical guide (3rd ed.). Routledge.

Koskey, K. L., \& Benson, S. N. K. (2017). A review of literature and a model for scaffolding asynchronous student-student interaction in online discussion forums. In P. Vu, S. Fredrickson, \& C. Moore (Eds.), Handbook of research on innovative pedagogies and technologies for online learning in higher education (pp. 263-280). IGI Global.

LaPointe, L., \& Reisetter, M. (2008). Belonging online: Students' perceptions of the value and efficacy of an online learning community. International Journal on E-learning, 7(4), 641-665.

Lederer, A. M., Hoban, M. T., Lipson, S. K., Zhou, S., \& Eisenberg, D. (2021). More than inconvenienced: The unique needs of U.S. college students during the COVID-19 pandemic. Health Education \& Behavior, 48(1), 14-19. https://doi.org/10.1177/1090198120969372.

Lee, M. H., \& Tsai, C. C. (2010). Exploring teachers' perceived self efficacy and technological pedagogical content knowledge with respect to educational use of the world wide web. Instructional Science, 38(1), 1-21. https://doi.org/10.1007/s11251-008-9075-4.

Lee, A. Y., \& Wang, K. J. (2019). Young people's media use and social participation in Hong Kong: A perspective of digital use divide. In E. Morrell \& J. Rowsell (Eds.), Stories from inequity to justice in literacy education: Confronting digital divides (pp. 110-129). Routledge.

Lee, S. J., Srinivasan, S., Trail, T., Lewis, D., \& Lopez, S. (2011). Examining the relationship among student perception of support, course satisfaction, and learning outcomes in online learning. The Internet and Higher Education, 14(3), 158-163. https://doi.org/10.1016/j.iheduc.2011.04.001.

Lee-Post, A., \& Hapke, H. (2017). Online learning integrity approaches: Current practices and future solutions. Online Learning, 21(1), 135-145.

Li, J. (2014). 'I am not leaving home': Post-80s' housing attitudes and aspirations in Hong Kong. Urban Research Group - CityU on Cities Working Paper Series, WP No.2/2014, 1-17. https://doi.org/10. 2139/ssrn.2347914.

Liu, P. (2019). Hong Kong tops the table as world's most expensive housing market for 9th straight year. South China Morning Post. https://www.scmp.com/business/article/2182980/nothing-be-proudhong-kong-tops-table-worlds-most-expensive-housing-market.

Maguire, M., \& Delahunt, B. (2017). Doing a thematic analysis: A practical, step-by-step guide for learning and teaching scholars. All Ireland Journal of Higher Education, 9(3).

Martin, F., \& Bolliger, D. U. (2018). Engagement matters: Student perceptions on the importance of engagement strategies in the online learning environment. Online Learning, 22(1), 205-222. https:// doi.org/10.24059/olj.v22i1.1092.

Mattar, J. (2018). Constructivism and connectivism in education technology: Active, situated, authentic, experiential, and anchored learning. Revista Iberoamericana de Educación a Distancia, 21(2), 201-217.

McNaught, C. (2004). Using narrative to understand the convergence of distance and campus-based learning during the time of SARS in Hong Kong. Educational Media International, 41(3), 183-193.

Miles, M. B., \& Huberman, A. M. (1994). Qualitative data analysis: An expanded sourcebook. Sage.

Moore, M. G. (1993). Theory of transactional distance. In D. Keegan (Ed.), Theoretical principles of distance education. Routledge.

Moore, M. G. (2007). Theory of transactional distance. In M. G. Moore (Ed.), Handbook of distance education (pp. 89-101). Lawrence Erlbaum.

Moore, M. G., \& Kearsley, G. (2012). Distance education: A systematic view of online learning. Wadsworth Cengage Learning.

Moorhouse, B. L. (2020). Adaptations to a face-to-face initial teacher education course 'forced' online due to the COVID-19 pandemic. Journal of Education for Teaching, 46(4), 609-611. https://doi.org/ $10.1080 / 02607476.2020 .1755205$.

Moos, D. C., \& Bonde, C. (2016). Flipping the classroom: Embedding self-regulated learning prompts in videos. Technology, Knowledge and Learning, 21(2), 225-242. https://doi.org/10.1007/ s10758-015-9269-1. 
Muilenburg, L. Y., \& Berge, Z. L. (2005). Student barriers to online learning: A factor analytic study. Distance Education, 26(1), 29-48. https://doi.org/10.1080/01587910500081269.

National Center for Education Statistics. (2019). Distance learning. https://nces.ed.gov/fastfacts/display. asp?id=80.

Northrup, P. T. (2002). Online learners' preferences for interaction. Quarterly Review of Distance Education, 3(2), 219.

Northrup, P. T. (2009). Online learners' preferences for interaction. In M. Simonson, T. L. Hudgins, \& A. Orellana (Eds.), The perfect online course: Best practices for designing and teaching (pp. 463-473). Information Age Publishing.

O'Cathain, A., \& Thomas, K. J. (2004). "any other comments?" open questions on questionnaires-a bane or a bonus to research? BMC Medical Research Methodology, 4(1), 1-7. https://doi.org/10.1186/ 1471-2288-4-25.

Palloff, R. M., \& Pratt, K. (2011). The excellent online instructor: Strategies for professional development. Wiley.

Patil, N. G., \& Chan, H. Y. Y. (2003). SARS and its effect on medical education in Hong Kong. Medical Education, 37(12), 1127-1128. https://doi.org/10.1046/j.1365-2923.2003.01723.x.

Prior, D. D., Mazanov, J., Meacheam, D., Heaslip, G., \& Hanson, J. (2016). Attitude, digital literacy and self efficacy: Flow-on effects for online learning behavior. The Internet and Higher Education, 29, 91-97. https://doi.org/10.1016/j.iheduc.2016.01.001.

Robinson, C., \& Hullinger, H. (2008). New benchmarks in higher education: Student engagement in online learning. Journal of Education for Business, 84, 101-109. https://doi.org/10.3200/JOEB. 84.2.101-109.

Ruey, S. (2010). A case study of constructivist instructional strategies for adult online learning. British Journal of Educational Technology, 41(5), 706-720.

Saba, F. (2007). A systems approach in theory building. In M. G. Moore (Ed.), Handbook of distance education (pp. 43-57). Lawrence Erlbaum.

Saldaña J. (2009). The coding manual for qualitative researchers. Sage Publications Ltd. https://doi.org/ 10.1111/j.1467-8535.2009.00965.x.

Sankey, M., Birch, D., \& Gardiner, M. (2010). Engaging students through multimodal learning environments: The journey continues. In Proceedings ASCILITE 2010: 27th annual conference of the Australasian Society for Computers in Learning in Tertiary Education: Curriculum, technology and transformation for an unknown future (pp. 852-863). University of Queensland.

Sher, A. (2009). Assessing the relationship of student-instructor and student-student interaction to student learning and satisfaction in web-based online learning environment. Journal of Interactive Online Learning, 8(2), 102-120.

Shurygin, V. Y., \& Krasnova, L. A. (2016). Electronic learning courses as a means to activate students' independent work in studying physics. International Journal of Environmental and Science Education, 11(8), 1743.

Smart, K. L., \& Cappel, J. J. (2006). Students' perceptions of online learning: A comparative study. Journal of Information Technology Education: Research, 5(1), 201-219.

Society for Community Organization. (2020). Xīnguān fèiyán yì zhèng cuòshī duì jīcéng értóng de y̌̌ngxiăng wènjuàn diàochá bàogào [A report on the impacts of COVID-19 on grassroots children]. https://soco.org.hk/wp-content/uploads/2014/10/Finalized_soco\%E6\%96\%B0\%E5\%86\%A0\%E8\% 82\%BA $\%$ E7\%82\%8E\%E7\%96\%AB\%E7\%97\%87\%E6\%8E\%AA\%E6\%96\%BD\%E5\%B0\%8D\%E5\% 9F\%BA\%E5\%B1\%A4\%E5\%85\%92\%E7\%AB\%A5\%E7\%9A\%84\%E5\%BD\%B1\%E9\%9F\%BF\%E5\% 95\%8F\%E5\%8D\%B7\%E8\%AA\%BF\%E6\%9F\%A5report_15_Mar_2020.pdf

Song, L., Singleton, E. S., Hill, J. R., \& Koh, M. H. (2004). Improving online learning: Student perceptions of useful and challenging characteristics. The Internet and Higher Education, 7(1), 59-70. https://doi.org/10.1016/j.iheduc.2003.11.003.

Sun, A., \& Chen, X. (2016). Online education and its effective practice: A research review. Journal of Information Technology Education, 15, 175-190.

The Hong Kong Polytechnic University. (n.d.). Notebook computers / tablets loan. https://www.lib.polyu. edu.hk/services/it-support/notebook-loan.

The University of Hong Kong. (2019). Laptop/tablet loaning program. https://lib.hku.hk/techsupport/ laptoploan.html.

Tsai, M. J. (2009). The model of strategic e-learning: Understanding and evaluating student e-learning from metacognitive perspectives. Journal of Educational Technology \& Society, 12(1), 34-48. 
Tu, C. H. (2001). How Chinese perceive social presence: An examination of interaction in online learning environment. Educational Media International, 38(1), 45-60. https://doi.org/10.1080/0952398001 0021235 .

Vonderwell, S. (2003). An examination of asynchronous communication experiences and perspectives of students in an online course: A case study. The Internet and Higher Education, 6(1), 77-90. https:// doi.org/10.1016/S1096-7516(02)00164-1.

Wang, A. Y., \& Newlin, M. H. (2001). Online lectures: Benefits for the virtual classroom. T.H.E. Journal, 29(1), 17-24.

Wong, E. T. T. (2004). Impact of e-learning during SARS outbreak in Hong Kong. In M. Khosrowpour (Ed.), The social and cognitive impacts of e-commerce on modern organizations (pp. 85-208). Information Resources Management Association.

Wong, T. W., Gao, Y., \& Tam, W. S. W. (2007). Anxiety among university students during the SARS epidemic in Hong Kong. Stress \& Health: Journal of the International Society for the Investigation of Stress, 23(1), 31-35. https://doi.org/10.1002/smi.1116.

Wong, J., Baars, M., Davis, D., Van Der Zee, T., Houben, G. J., \& Paas, F. (2019). Supporting selfregulated learning in online learning environments and MOOCs: A systematic review. International Journal of Human-Computer Interaction, 35(4-5), 356-373. https://doi.org/10.1080/10447318. 2018.1543084.

Yeung, K. (2020). Suspending Classes without Suspending Learning. Education Bureau. https://www. edb.gov.hk/en/about-edb/press/insiderperspective/insiderperspective20200212.html.

Zhong, R. (2020). The coronavirus exposes education's digital divide. New York Times. https://www. nytimes.com/2020/03/17/technology/china-schools-coronavirus.html.

Zull, J. (2011). From brain to mind: Using neuroscience to guide change in education. Stylus Publishing.

Publisher's note Springer Nature remains neutral with regard to jurisdictional claims in published maps and institutional affiliations. 